\title{
ブリッジマン法による金属単結晶の作製と 表面処理研究への応用
}

\author{
渡辺徹*, 中 田 \\ 毅** \\ Fabrication of Metal Single Crystal by Bridgmann Method \\ and Application of it for Investigation of Surface Treatment
}

Tohru WATANABE* and Takeshi NAKATA**

Key Words : Single Crystal, Bridgmann Method, Surface Treatment, Cu, Al

銅やアルミニゥムなどの金属単結晶の作製方法の実際と，単結晶を使った表面処理技術，特にめっき技術 と陽極酸化技術に関する研究例について解説する。

\section{1 .はじめに}

めっき技術や陽極酸化皮膜など，表面を用いる技術は ますます重要な技術となり, より高機能化が要求されて きている。形成される皮膜材料の特性が高機能化や高精 密化をめざすとき，形成される膜そのものの結晶学的な 構造について詳細に知らなければならない。結晶質材料 のほとんどの物性は結晶の方位によって異なる（結晶異 方性）からである。また膜そのあのの構造の詳細が分か ると，その膜の構造が素地材料の結晶学的構造の影響を 強く受けていることがわかる。そのため, 皮膜の結晶学 的構造を制御しょうとすれば，素地材料の構造から見直 さなければならなくなる。金属材料のほとんどは結晶質 である。めっき膜もそのような金属材料そのあのである。 最近では Si な゙の半導体材料が単結晶を使っているこ とは有名であるが，金属の機械材料そのあのを単結晶で

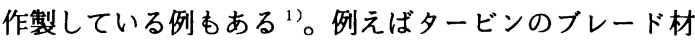
としてステンレスティールが用いられるが，そのスティー ルを単結晶で作製し，単結晶の変形抵抗の最も大きな方 向を力のかかる方向に並べることによって，より強度の 高い，また軽量化したタービンを作製し，タービンの高 性能化に成功している ${ }^{2)}$ 。

本論文はこのような研究をする時の, 単結晶の作製方 法と，単結晶を用いた表面処理技術に関する研究の例に

* 東京都立大学 工学部（干192-03 東京都八王子市南大沢 1-1） Fac. of Tech., Tokyo Metropolitan Univ. (1-1, Minami Osawa, Hachioji-shi, Tokyo 192-03)

**芝浦工業大学（广108 東京都港区芝浦 3-9-14）

Shibaura Inst. of Tech. (9-14, Shibaura 3-chome, Minato$\mathrm{ku}$, Tokyo 108)
ついて紹介する。

\section{2. 単結晶の作製の原理 ${ }^{3)}$, 4)}

一般に金属単結晶の作製はブリッジマン法（一方向凝 固）による。この方法を簡単に述べると，るつぼで金属 を溶解し，そのるつぼを底の方から電気炉の外へゆっく り引き出すか，または電気炉を引き上げて，るつぼの底 にできた一つの結晶核をゆっくり成長させる。このよう にして融液全体を疑固させ，るつぼの内にロッド状の単 結晶を作製する方法である。

このブリッジマン法の良いところは，溶融金属中の不 純物元素は凝固したロッドの最上部に濃縮され, 形成さ れた単結晶は溶解する前の素材よりあ必ず純度が上がる ことである。この純度の上がる原理は次のように金属の 熱平衡状態図で説明できる ${ }^{4)}{ }^{5)}$ 。

例えば, 図 1(1) は $\mathrm{A}$ 金属と $\mathrm{B}$ 金属との熱平衡状態図 の一部を示している。この図で，あし $\mathrm{A}$ 金属の中に不純 物元素である B金属が $a_{1} \%$ 混入していてあ，最初に凝 固する固体は必ず $a_{2} \% \mathrm{~B}$ の純度の上がった組成のもの である。そしてるつぼの下の方で A金属が疑固を始め, 凝固界面が上へと移動してあそのつど疑固してゆく結晶

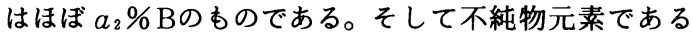
B金属は上部の融液の中へ押しやられる。このようにし て形成される単結晶は純度が上がり， $a_{2} \% \mathrm{~B}$ 単結晶が でき上がる。

しかし，試料の最上部は B金属が濃縮された固体であ る。それで, この部分を切り除いて, 再度一方向凝固を させると（図 1 (2)), 残存した不純物は再びロッドの最 上部に濃縮され， $a_{3} \% \mathrm{~B} ま て ゙$ 純化した固体ができる。こ 
(1)

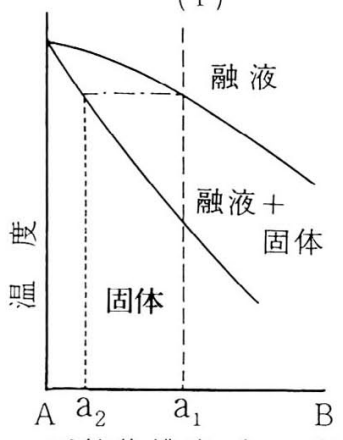

(2)

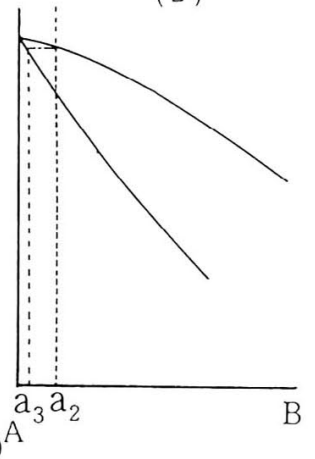

(3)

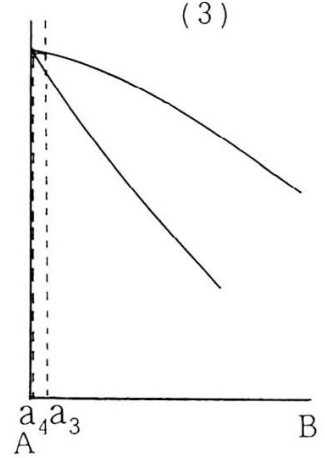

図 1 ブリッジマン法による単結晶作製時の金属の純度向上に関する熱平衡状態図からの説明

の操作を何度も繰り返せば，原理的には無限に純度の高 い結晶ができる。

逆に, ブリッジマン法によって合金の単結晶を作製す るには土夫がいることになる。というのは得られる固体 は最初にるつぼに入れて溶解した素材と異なった組成の あのとなるからである。従って合金の単結晶を作製する 場合は，熱平衡状態図を正確に読んで，作製したい合金 組成に見あった，より濃度の高い組成の素材を用いる必 要がある。例えばジュラルミン（Al- $5 \mathrm{wt} \% \mathrm{Cu}$ 合金） の単結晶を作製するには，原理的にはほぼ $30 \mathrm{wt} \% \mathrm{Cu} の$ 素材を用いなければならず，一回の一方向凝固で作製し なければならないことを意味する。

さらにブリッジマン法では同素变態のある金属，たと えば純 $\mathrm{Fe} や \mathrm{Co}$ の単結晶を作ることはできない。融䘸 から常温に温度が下がる間に, 鉄では $1,400^{\circ} \mathrm{C}$ と $910^{\circ} \mathrm{C}$

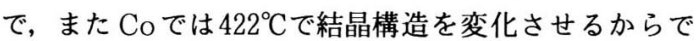
ある。この場合はブリッジマン法を用いず，歪焼鈍法を
用いる。これは再結晶を用いるあので，加工歪を与えた 金属を再結晶温度以上に加熱しておき，それを冷却した 金属のスリットを通して冷却する方法である。この場合, 板状の単結晶しか得られず，結晶方向む制御することは できない。

また前述した合金の単結晶を作製するには全率固溶体 合金か，または例えば Cu-Zn合金では33at\%Zn以下， $\mathrm{Ag}-\mathrm{Zn}$ では $30 \mathrm{at} \% \mathrm{Zn}$ 以下の固溶体の組織を持つ組成範 囲のものでなければならない。逆に金属間化合物の単結 晶の作製については熱平衡状態図を参考にするとこのブ リッジマン法で作製可能である ${ }^{5)}$

\section{3. 単結晶作製の実際}

$\mathrm{Al}$ および $\mathrm{Cu}$ の単結晶作製装置の作製や，それによ る単結晶そのものの作製は比較的容易で, 著者らは $\mathrm{Al}$ の場合は直径 $50 \mathrm{~mm}$ のものも作製した。その装置を図 2 (a)，(b)に示す。また，その装置による単結晶の作製

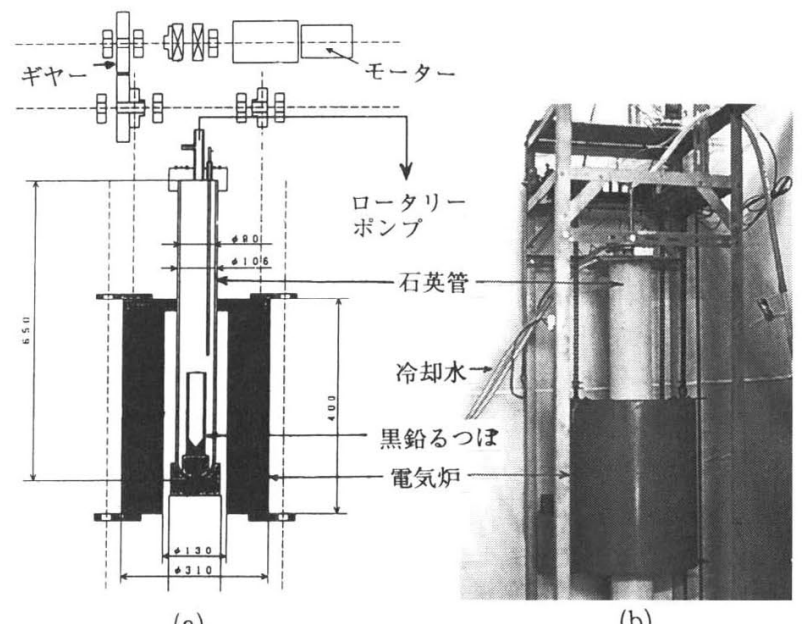

(a)

(b)

図 2 ブリッジマン単結晶作製装置 (a) とその写真 (b) 


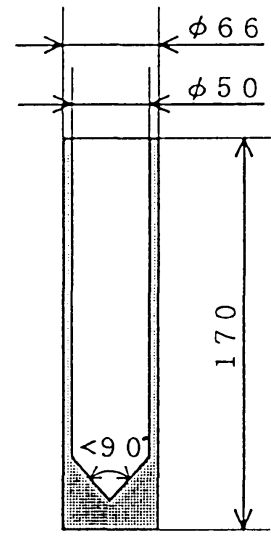

図 3 黒鈆るつぼの形状

は次のようである。

\section{1 るつほの材質}

るつぼの材質は黒鉛で，長さおよび内径は必要に応じ て適当な大きさとする（図 3)。著者らは $\mathrm{Cu}$ では直径 $20 \mathrm{~mm}$, 長さ $170 \mathrm{~mm}$ のあの, $\mathrm{Al}$ では直径 $50 \mathrm{~mm}$ 長さ $170 \mathrm{~mm}$ のものを作製した。さらに大きなるの，また板 材など，形の違ったあのあ作製可能である。

黒鉛るつぼの壁面はできるだけ滑面がよい。るつぼは むくの黒鉛材料から旋盤によってえぐり出して作られる ので, 内部の表面状態を見ることは困難である。その時 は一度金属を溶解し，凝固したロッドの表面を見ること によってるつぼの表面状態を見ることができる。あまり よくないことが多い。それで，エミリーペーパーで手で 研磨して仕上げるとよい。

黒鉛るつぼの壁厚は $3 \sim 5 \mathrm{~mm}$ 。るつぼの底の V字の 角度は 90 度であ良いが，それ以下(鋭角)であればよい。 得られる単結晶の成長方位は全く不定で, 得られる試料 の軸方位が何であるか出来て見なければ分からない。種 結晶を用いて，得られる結晶の方位を任意に制御するこ とあ行われるい。これはるつぼの底に結晶方位のわかっ た小さな細長い単結晶をセットし, 電気炬で素材を溶解 する時に，セットされた種結晶の一部（上部）を溶解し， その部分にこれから凝固させようとする溶けた金属素材 を接触させて一方向凝固を開始させる方法である。この ようにすれば種結晶と同じ方位の結晶を大きく成長させ ることができる。しかし実際には種結晶を作製する手間 と，その種結晶の一部のみを溶解し，それを溶解した素 材金属と接触させる技術の難しさを考えるとかなり面倒 である。それで，方位は分からずとあ，とにかく単結晶 を得ておき，その結晶方位をラウエーカメラで観察し， そこから必要な結晶方位の試料をゴニオステージを用い て切り出して得る方が容易である。

黒鉛るつぼは図 2 のように石英管の中に入れられ，石
英管内は真空に引かれる。真空にする目的は，溶解した 金属が酸化されないためと，黒鉛るつぼが燃えないで, 寿命を長くするためである。それには $1 \sim 5 \times 10^{-3} \mathrm{~mm}$ $\mathrm{Hg}$ 程度（ロータリーポンプで引く程度）でよい。黒鈆 るつぼは溶解した金属がしみ出さない程度にポーラスな あので，真空を引くとるつぼの壁面を通して，るつぼの 底の部分あ真空に引かれる。

\section{2 電気妒}

使用する電気炉の特性をあらかじめ調べておく必要が ある。また，電気炉に石英管を入れ，さらに溶解する金 属の入ったるつぼを入れた状態での温度分布を見ると， かなり平坦である。金属の熱伝導の良さを考えると, 高 温に加熱している時にはるつぼに入っている素材全体が 溶解していると考えられる。しばしば凝固した固体と融 液との温度傾斜は急激なほど良いように書かれている ${ }^{6)}$ が，実際にはゆるやかでああまり問題はない。

\section{3 引き上げ速度}

電気炉の引き上げ速度, 即ち冷却速度と温度勾配と形 成される結晶の構造との関係について堂山らは温度勾配 が大きく，凝固速度は遅いほどよいと報告している ${ }^{6)} 。$ 著者らの作った装置では $\mathrm{Al}$ では $4.3 \times 10^{-2} \mathrm{~mm} / \mathrm{s}, \mathrm{Cu}$ では $1.3 \times 10^{-2} \mathrm{~mm} / \mathrm{s}$ で行った。この速度はあまり厳密 なあのではなく，これを目安にするとよい。引き上げ時 間は単結晶の長さに関係し，試料全体が凝固するまで引 き上げる。冷却された単結晶は凝固時より体積収縮して いるため，黒鉛るつぼから簡単に取り出すことができる。

\section{4 試料の判定と結晶面の出し方}

得られた単結晶ロッドは， $\mathrm{Cu}$ の場合は希硝酸で，ま た $\mathrm{Al}$ の場合は $20 \%$ 水酸化ナトリウム溶液で表面を化学 エッチングする。単結晶ができておらず，粒界がある場 合は粒界が現れる。粒界が無く完全な単結晶であれば, 単結晶ができているが゙うか判定しにくい。できている 時はロッドを斜めにして回転させながら光沢の状態を眺 めると周期的に輝きが変わり，単結晶らしいことが確か められる。さらに確認するには，ロッドを高速カッター によって注意深く機械切断し，その断面を化学エッチン グして粒界の有無を確認する。図 4 は実際に作製された $\mathrm{Al}$ ロッド (a) とその断面 (b)，(c) である。(b)では周辺に 粒界が見られ，(c)では中央部にも粒界が見られる。完 全な単結晶ではこのような粒界は見られない。一回の引 き上げで単結晶にならない場合は, 2 度 3 度と一方向凝 固をさせて単結晶とする。その際, 不純物が上部に濃縮 されているので, ロッドの最上部はそのつど $15 \mathrm{~mm}$ ほ ど削除する。

試料の切断面を化学エッチングして, 粒界が無くなっ たと考えられる試料はラウエー写真によって結晶の成長 方位を確認する。ラウエー写真の撮影方法や解析方法 ${ }^{7)}$ はここでは省略する。一般にロッドの成長方位は規則性 

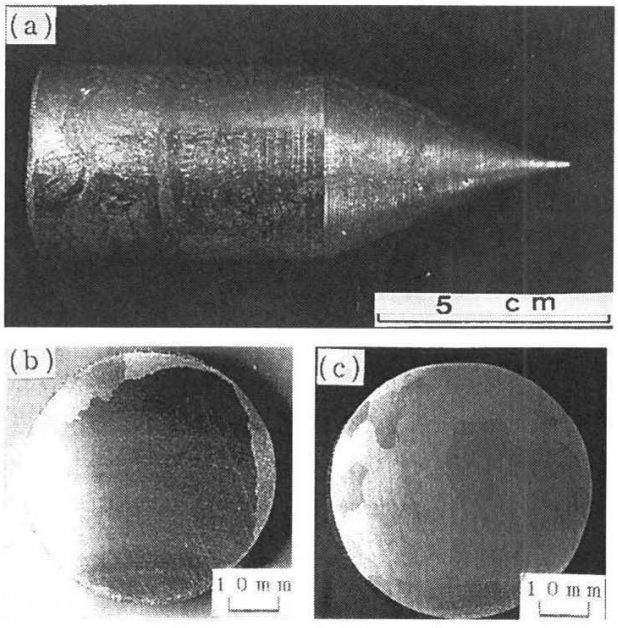

図4作製された $\mathrm{Al}$ 単結晶(a)と, 完全に単結晶になっていな いものの断面構造 (b), (c)

が無く、種結晶を使わない限り全く予測することはでき ない。それで，ロッドの軸に垂直な断面で測定し，そこ から必要な結晶の方位の角度を予測し，ゴニオメターの ついた精密切断機で切断し, 試料とする。ただ，機械切 断するとき,ゴニオステージに単結晶試料を固定する方 法が問題である。万力などで強く締め付けて固定すると, 単結晶試料は純度が高く, 軟らかいので, 万力の当たっ た部分が変形し，せっかくの試料が台無しになる。それ で，しばしば，軟らかいセラミック板の上に接着剂で固 定し, 高速カッターでセラミックス台の一部を切りなが ら切断する方法がとられる。著者らは，金属の帯で締め 付けて固定する方法をとった。

高速カッターで切断できる最低の板厚は, 金属の種類 にあよるが,いずれにしてあ $0.5 \mathrm{~mm}$ 以下は難しいだろ う。機械切断した試料の表面は加工变質層や加工歪が約 $0.25 \mathrm{~mm}$ 厚で入っているので, その加工層は化学研磨か, 電解研磨によって完全に溶解除去する必要がある。そう しないとラウエー写真の回折斑点が明瞭に現れない。ま たラウエー写真による結晶方位の判定は $\pm 2{ }^{\circ}$ 程度の誤
差はやむをえない。

\section{4. 単結晶の表面処理技術研究への応用}

\section{1 めっき技術}

電析および無電解めっき法で析出する薄膜（いわゆる めっき膜）はいずれも金属薄膜である。そのため, 素地 材料が金属材料であればいずれの場合も金属結合によっ て密着し, めっき膜と素地金属とは結晶学的な整合をと $3^{8)}$ (エピタキシャル成長)。また，めっき膜は整合成 長するため, 厚さを増加させるとその表面形態も素地の 結晶方位によって大きく異なる ${ }^{9)}$ 。例えば, 図 5 は純銅 多結晶板の表面 (a)であり, 銅の数十 $\mu \mathrm{m}$ 径の結晶粒が よく観察される。結晶の白黒のコントラストは結晶の方 位の違いによる。(b) はその結晶粒の上に形成された Ni めっき膜であるが, 素地の結晶粒の方向によって表面形 態が異なっている。素地結晶の方位によっては大きな凹 凸ができる場合むあるが, 凹凸がほとんどできない方位 あある。図 6 は素地が $\{100\},\{110\}$, および $\{111\}$ の表 面を持つ純 $\mathrm{Cu}$ の単結晶の上に電析法で $\mathrm{Au}$ をめっきし たときの,めっき膜の表面形態である。図中 (a)〜 (d) は めっき時間の経過（膜厚増加）を示している。 $\{100\}$ 素 地面上では初期には平板状のめっきであるが，時間とと あにピラッミッド状の結晶が成長している。また, $\{110\}$ 素地面では長屋の屋根形の結晶が長く伸びている。また $\{111\}$ 素地面上ではステップや 60 度または 120 度の角度 のキンクが見られる。しかし，いったいにめっき時間が 経過しても（膜が厚くなっても）平板状のめっきが成長 している。前二者（ $\{100\}$ 面と $\{110\}$ 面）はめっき時間 とともに凹凸の激しい表面形態になるが，\{111\}面では めっき膜が厚くなっても光沢のあるめっきが得られる。 このことはめっき膜の結晶が, 素地金属と結晶学的に整 合するためである。このことを知ると，めっき条件を選 ばなくとも，素地の結晶方位を制御することによって， めっき膜の表面形態を制御できることになる。

さらに, めっき膜の結晶学的配向性についても工業的 な意味から重要な研究テーマである。配向性を制御する ことができれば，硬さなどの機械的性質や磁気的性質な
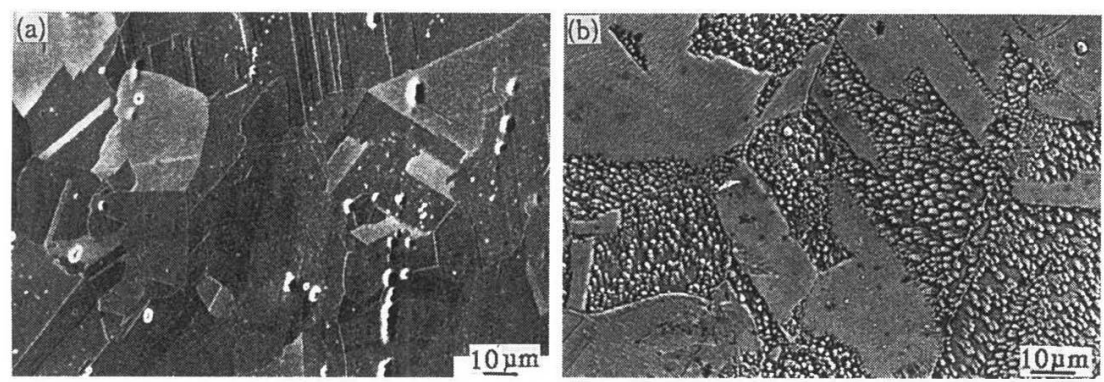

図 5 純 $\mathrm{Cu}$ 多結晶板表面 (a) とその上に形成された電析 $\mathrm{Ni}$ めっき膜の表面形態 (b) 
どの物理的性質，を制御することができる。例えば垂直 磁気メモリーの作製はこの配向性を制御したあのである。 このような研究には素地に単結晶を用いるか, 逆にアモ ルファスを使用すると便利である。一般に手に入る，圧 延された多結晶金属板は，圧延集合組織 10).11) を持って おり，それを焼き鈍しても，焼き鈍し集合組織（再結晶 集合組織) ${ }^{111}$, 12) を持っている。これらは, 多結晶の金属 材料を压延すると， ある結晶面が統計的に表面に出やす く,さらにそれを再結晶させても, やはり再結晶させた なりの結晶学的な面を表面に出す。このような集合組織 の素地の上にめっきを行い, めっき膜の配向性について X線回折法によって検討すると, めっき膜は素地に整合 しているため, 素地の集合組織をめっき膜の配向性と誤
認する危険性がある。

\section{4. $2 \mathrm{Al}$ の陽極酸化}

金属の腐食電位などの化学的性質は金属の結晶学的な 面によって異なる。例えば, $\mathrm{Al} の 0.1 \mathrm{M} \mathrm{NaCl}$ 溶液中 での電流一電位曲線は図 $7^{13)}$ の如くで, 曲線は $\{100\}$, $\{110\},\{111\}$ 面の順でアノーディックな方向にシフトし ている。熱処理した多結晶試料は $\{110\}$ 面と $\{111\}$ 面の間 である。またエッチング処理による $\mathrm{Al}$ の表面の腐食形 態も図 $8{ }^{13)}$ のように異なる。\{111\}面では三角錘状のピッ 卜ができ, $\{110\}$ 面では $V$ 字谷状の腐食孔， $\{100\}$ 面では 4 角形のピットとなる。この腐食孔の形状は f fc 結晶で は $\{111\}$ 面が最も安定な結晶面であるためで，この $\{111\}$ 面を表面に出すためである。このことは図 5 のめっきの
(1) $\{100\} \mathrm{C} \mathrm{u}$
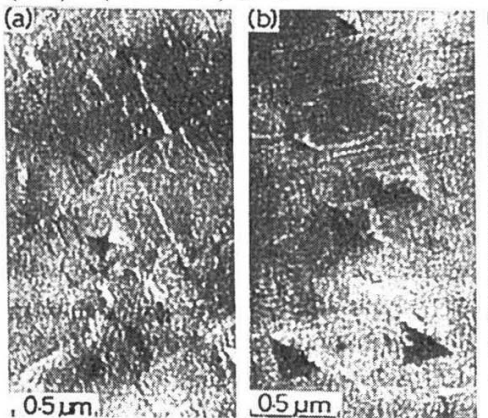

(2) $\{110\} \mathrm{C} \mathrm{u}$
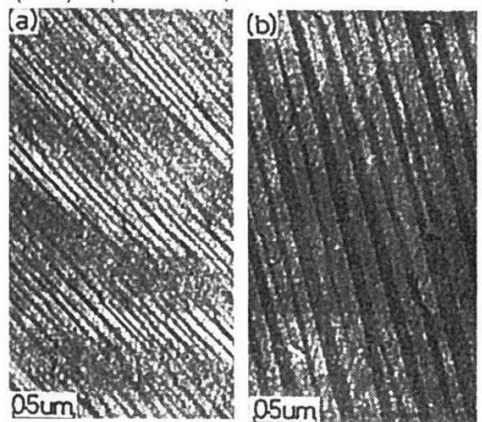

(3) $\{111\} \mathrm{C} \mathrm{u}$

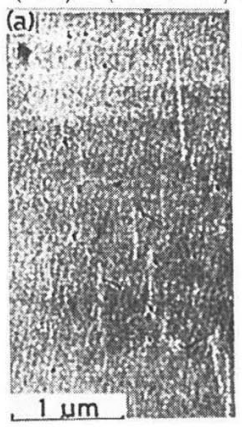

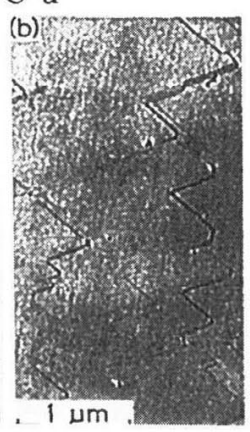
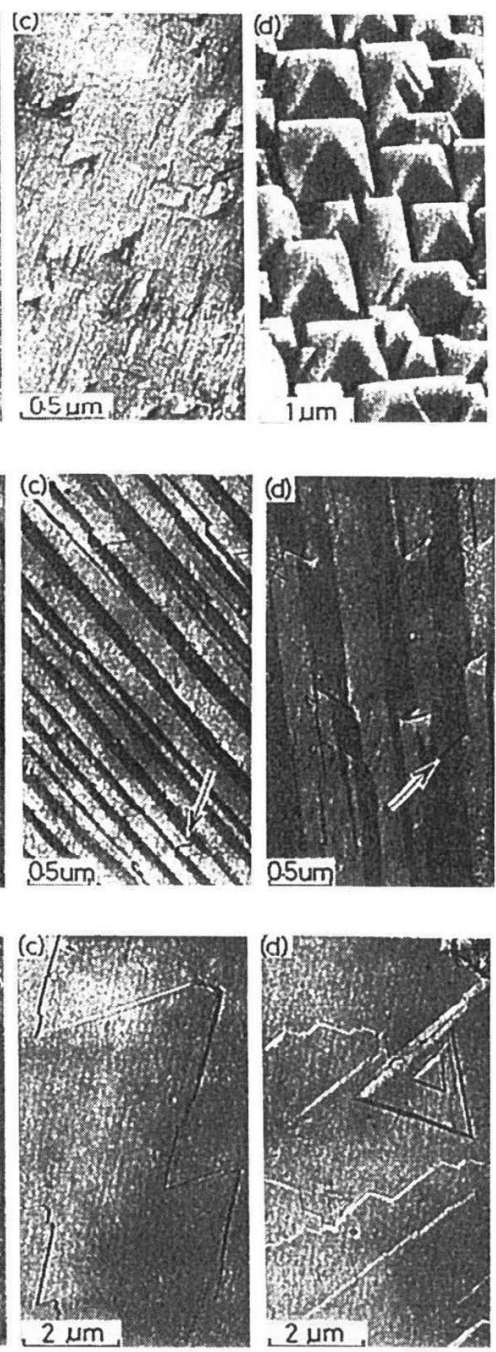

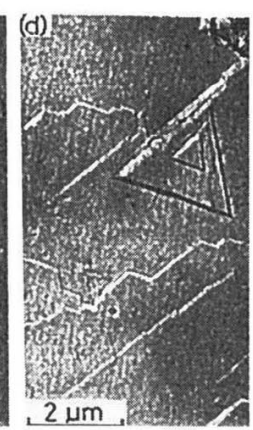

图 $6 \mathrm{Cu}$ 単結晶表面に電析された $\mathrm{Au}$ めっき膜の表面形態

(a)〜(d) はめっき時間の経過（平均膜厚の增加）を示す。 


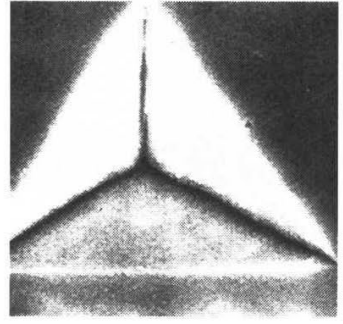

(a) $\{111\}$ Al面

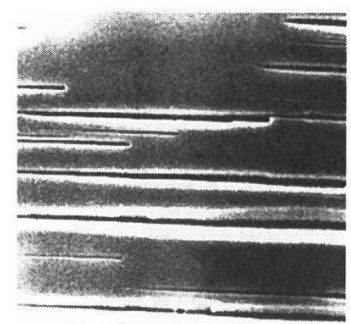

(b) $\{11$ () $\}$ A 1 面

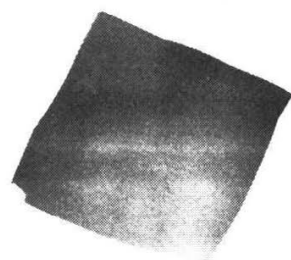

(c) $\{10(0|\mathrm{~A}|$ 面

图 $8 \mathrm{Al}$ 単結晶のエッチングルよるピットの形状

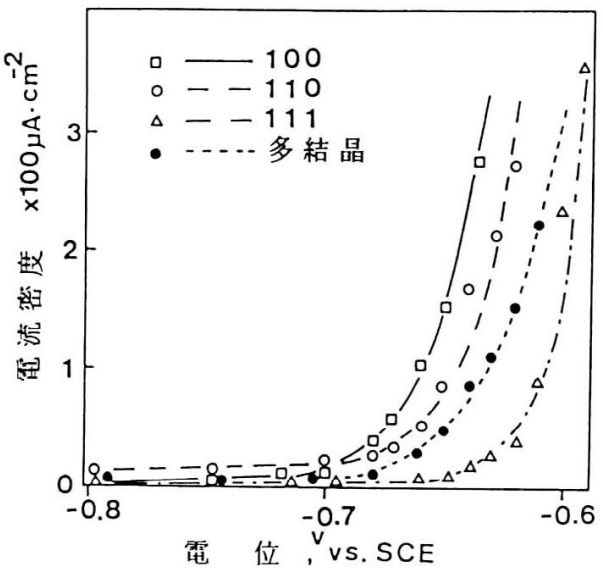

図 $7 \mathrm{Al}$ 単結晶および $\mathrm{Al}$ 多結晶表面の $0.1 \mathrm{M} \mathrm{NaCl}$ 溶液中電流 電位曲線 $\left(30^{\circ} \mathrm{C}\right)$

場合之同様である。図 9 は定電流化成時の各結晶面にお ける化成時間之化成電圧の関係 ${ }^{13)}$ である。このグラフか ら $\{111\} ，\{110\},\{100\}$ 面の順で化成電圧の低下がうか がわれる。以上のことから，Al の表面に形成される陽 極酸化皮膜の形成状況もその金属の結晶方位によって異 なることが推測される。事実皮膜の形成は $\{111\}$ 面にお いて最も増大する結果が得られている ${ }^{13)}$ 。

\section{5. おわりに}

冒頭に書いたように，金属はほとんどの場合結晶質で ある。結晶はその結晶方位によって機械的, 物理的, 化 学的性質を異にする。形成される膜の結晶異方性を知り, それを制御することができれば，より高機能な表面処理 や機能材料の作製が可能となる。今後は表面技術のみな らず，種々な工業用材料で単結晶を用いる試みあ出てく ると考えられる。

\section{謝辟}

本論文を書くに当たり，多くの資料を提供して下さっ た松澤繁光氏（エヌ・イーケムキャット(侏）に深謝致し ます。

(1994-7-15 受理)

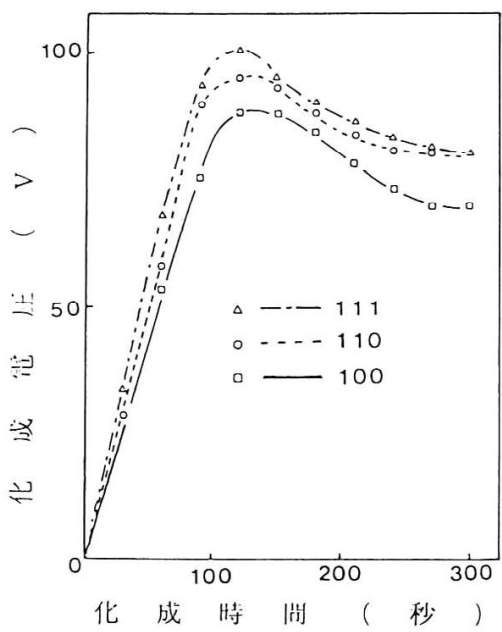

図 $9 \mathrm{Al}$ 単結晶の化成時間と化成電圧の関係

\section{文献}

1) 太田芳雄, 中川幸也, 大友 暁, 雑賀喜規 ; 日本金属学会 報, 24, 462 (1985)

2）出川 通; 日本金属学会報, 30,763 (1991)

3 ) 山本美喜雄; 日本金属学会誌, 18, 519 (1954) 勇田敏男, 田頭孝介; 精密機械, 39, 312（1973）

4 ）日本金属学会編集; 金属物性基礎講座, 第 17 巻, 結晶成長 (丸善, 1975)

5 ） 日高義和；日本金属学会報，29，689（1990）

6 ) 堂山昌男; 単結晶, p.13 (内田老鶴围, 1990)

7 ) B. D. Cullity 著, 松村源太郎訳; X線回折要論（アグネ, 1964)

8 ）渡辺 徹；金属表面技術，39，440（1986）

9 ）渡辺 徹；表面技術，41，652（1990）

10）森井賢二，中山 豊；日本金属学会報，25，404（1985） H. Hu, R. S. Cline and S. R. Goodmann; Recrystallization, Grain Growth and Textures, ASM Seminar, p.295 (1965)

野田龍彦; 日本金属学会報, 19, 638 (1980)

11）北川 孟; 日本金属学会報, 28, 277 (1989)

12）武 智弘; 日本金属学会報, 26，619（1987）

13）松澤繁光;「アルミニゥム陽極酸化皮膜の成長および孔食に およぼす結晶方位の影響に関する研究」東京都立大学工学部, 博士論文 (1980)

14) S. Matsuzawa, N. Baba and S. Tajima ; Electrochimica Acta, 26, 161 (1981) 